\title{
Analisis Faktor Determinan Perilaku Pencegahan Covid-19 di Kelurahan Kapasa Makassar
}

\author{
Siprianus Abdu, Jenita Laurensia Saranga', Dhanty Jovica Dangeubun, Dian Novita Sari \\ Program Studi Sarjana Keperawatan, Sekolah Tinggi Ilmu Kesehatan Stella Maris Makassar
}

\section{Info Artikel \\ Riwayat Artikel: \\ Received : 15 November 2021 \\ Revised : 27 November 2021 \\ Accepted : 02 Desember 2021}

\section{Kata Kunci:}

Faktor determinan

Perilaku pencegahan

Covid-19

\begin{abstract}
ABSTRAK
Perilaku preventif yang diharapkan selama masa pandemi covid-19 ini adalah penerapan protokol kesehatan seperti memakai masker, mencuci tangan dan menjaga jarak dan ini sudah menjadi kebiasaan baru (new normal). Penyebaran covid-19 perlu diakhiri sebab berdampak pada hampir seluruh sendi kehidupan, namun di sisi lain masyarakat kita kurang patuh menerapkan protokol kesehatan. Penelitian ini bertujuan untuk mengetahui faktor-faktor yang berhubungan dengan perilaku pencegahan covid-19. Jenis penelitian yang digunakan adalah observasional analitik dengan pendekatan crossectional study. Teknik sampling menggunakan metode nonprobability sampling dengan pendekatan Consecutive Sampling dengan jumlah sampel 100 orang. Instrumen penelitian yang digunakan dalam penelitian ini berbentuk kuesioner. Data yang terkumpul selanjutnya diolah dengan menggunakan SPSS versi 24 dan dianalisis secara univariat dan bivariat. Hasilnya adalah kategori usia terbanyak dewasa $75 \%$, kategori jenis kelamin terbanyak perempuan $61 \%$, kategori tingkat pendidikan terbanyak adalah pendidikan menengah $47 \%$, kategori pengetahuan terbanyak baik $59 \%$, dan kategori perilaku pencegahan covid-19 terbanyak baik $78 \%$. Hasil uji statistik Chi Square diperoleh nilai $p$ untuk masing-masing hubungan variabel adalah usia $(0,026)$, jenis kelamin $(0,968)$, pendidikan $(0,001)$ dan pengetahuan $(0,000)$ dengan tingkat signifikansi $\alpha=0,05$. Sehingga dapat disimpulkan bahwa untuk usia, pendidikan dan pengetahuan memiliki hubungan yang signifikan dengan perilaku pencegahan Covid-19 artinya orang yang dewasa, tingkat pendidikannya tinggi dan pengetahuan baik memiliki perilaku pencegahan covid19 yang baik. Namun untuk jenis kelamin tidak memiliki hubungan yang signifikan dengan perilaku pencegahan Covid-19, artinya seorang yang berjenis kelamin perempuan bisa saja memiliki perilaku pencegahan covid-19 yang kurang baik. Sehingga perlu kedewasaan, peningkatan kualifikasi pendidikan dan pengetahuan yang baik agar memiliki perilaku pencegahan covid-19 yang baik pula.
\end{abstract}

This is an open access article under the CC BY-SA license.

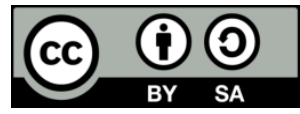

\section{Corresponding Author:}

Siprianus Abdu,

Program Studi Sarjana Keperawatan, STIK Stella Maris,

Jl Maipa No. 19, Makassar, Indonesia.

Email: siprianusabdu28@gmail.com

\section{PENDAHULUAN}

Covid-19 merupakan penyakit yang disebabkan oleh sebuah virus corona jenis baru yang menyerang makhluk hidup pada akhir tahun 2019 pertama kali di Kota Wuhan Cina, yang saat ini menyebabkan terjadinya pandemi hampir di semua bagian dunia. World Health Organization (WHO) China Country Office menyampaikan pada akhir tahun 2019 ditemukannya kasus klaster pneumonia dengan penyebab yang masih belum diketahui di Kota Wuhan China. Semenjak ditemukan kasus ini semakin bertambah sampai pada bulan Januari 2020, kemudian diketahui bahwa penyebab dari penyakit ini yaitu jenis baru dari corona virus yang sebelumnya belum pernah diidentifikasi pada manusia (Moudy \& Syakurah, 2020).

Tingkat kematian pada kasus ini masih terus terjadi, secara global pada bulan Mei 2020 kasus covid19 yang terjadi berjumlah 4.170.424 kasus, dengan jumlah 287.399 kasus kematian (WHO Report, 2020). Di Indonesia, penambahan jumlah kasus yang telah terkonfirmasi terus meningkat, dimana pada Bulan Mei 
berada pada angka 10.551 kasus dengan 800 orang meninggal dunia, akan tetapi hingga 16 Juni 2020 kasus bertambah cukup signifikan menjadi berjumlah 40.400 kasus dengan jumlah kematian sebanyak 2.231 kematian. Di Makassar jumlah kasus yang di konfirmasi pada 25 Juni 2020 berjumlah 2.535 kasus dengan 122 kasus kematian (Purnamasari \& Raharyani, 2020).

Menurut Nurislaminingsih (2020) bahwa pandemi covid-19 mempunyai bagian yang cukup unik. Dunia seolah mengenang kembali pandemi yang sama yang terjadi di London pada tahun 1981. Terdapat persamaan dari dua pandemi tersebut, yaitu penyakit yang disertai dengan keluhan flu namun mampu mengakibatkan banyak kasus kematian. Dampak yang diakibatkan oleh kedua wabah ini pun sama, yaitu lockdown di beberapa kota yang ada di berbagai negara, diperpanjangnya masa libur atau istirahat di rumah, adanya alur perawatan secara intensif di tempat-tempat pelayanan kesehatan khusus, hal ini membantu mengisolasi pasien dari jangkauan publik. Gejala-gejala yang umumnya muncul pada mereka yang terinfeksi covid-19 yaitu mereka memiliki tanda dan ciri seperti gangguan pernapasan yang muncul secara tiba-tiba, seperti panas tinggi, merasa sesak napas dan juga batuk. Masa bertahannya virus tersebut rata-rata 5-6 hari dengan masa bertahan terlama yaitu 14 hari. Pada beberapa kasus covid-19 yang memiliki tingkat terberat bisa mengakibatkan terjadinya gagal ginjal, pneumonia, adanya sindrom pernapasan akut, dan bahkan bisa mengakibatkan terjadinya kematian. Tanda dan gejala klinis dari covid-19 yang biasa ditemukan pada sebagian besar kasus ini adalah panas tinggi dan pada kasus lainya mengalami sesak napas, dan hasil rontgen menunjukkan adanya infiltrat pneumonia luas pada paru-paru.

Orang-orang yang berisiko terinfeksi covid-19 yaitu mereka yang terkontak langsung dengan orang yang telah terkonfirmasi positif covid-19. Sehingga perilaku pencegahan yang ada harus menjadi kunci penerapan pada pelayanan-pelayanan kesehatan dan masyarakat. Perilaku pencegahan awal yang bisa dilakukan yaitu setiap individu selalu menggunakan masker saat ingin berpergian keluar rumah, membasuh atau membersihkan tangan pada air mengalir serta memakai sabun, memakai hand sanitizer, tetap membatasi jarak diri dengan orang sekitar kurang lebih 1 meter dan saat batuk diharapkan menerapkan cara batuk atau bersin yang baik dan benar yaitu dengan cara tutup bagian hidung dan mulut menggunakan bagian dalam dari lengan atas ataupun menggunakan tisu (Wulandari et al., 2020).

Untuk mempertahankan kesehatan diri seseorang, ada dua faktor yang dapat mempengaruhi kesehatan, yaitu pertama faktor perilaku dan kedua faktor non-perilaku. Terdapat tiga domain/ranah dari perilaku, yaitu pengetahuan, sikap, dan tindakan. Perilaku kesehatan dapat ditentukan oleh tiga faktor lainnya yaitu faktor predisposisi, faktor pemungkin dan faktor pendorong/penguat. Bila dilihat dari faktor predisposisi, masyarakat sendiri mempunyai beberapa faktor yang disebut sosiodemografi yaitu adanya ketidaksamaan usia, jenis kelamin, pendidikan, pekerjaan, serta latar belakang pekerjaan dan daerah asal. Gambaran dari karakteristik sosiodemografi ini dapat juga mempengaruhi perilaku masyarakat serta outcome dari kesehatan masyarakat (Moudy \& Syakurah, 2020).

Pada penelitian Zhong et al (2020), ditemukan adanya suatu hubungan antara jenis kelamin dengan tindakan terhadap covid-19, laki-laki lebih berisiko mempunyai perilaku yang kurang baik seperti bepergian tidak menggunakan masker saat ke tempat-tempat yang ramai dibandingkan dengan perempuan. Selain jenis kelamin pada penelitian ini ditemukan juga hubungan signifikan lainnya berupa kelompok usia, tingkat pendidikan, dan juga asal daerah yang berpengaruh pada pola pikir dan pemahaman masyarakat mengenai covid-19.

Pengetahuan merupakan suatu cara seseorang agar dapat memperoleh, memahami, dan bisa menerapkan informasi, dimana hal-hal tersebut bisa terjadi karena adanya pengaruh dari pengalaman maupun keterampilan individu itu sendiri. Setengah dari informasi tambahan yang dimiliki individu tersebut muncul dari pendidikan baik secara langsung maupun tidak langsung, pengalaman kehidupan pribadi maupun individu lainnya, daerah sekitarnya, serta sosial media yang ada. Pengetahuan memegang peranan yang sangat penting dalam menentukan sifat dan kelakuan individu hal ini dikarenakan pengetahuan dapat menghasilkan adanya sebuah pemahaman dan kebiasaan. Pengetahuan yang diterima dan terus bertambah bisa membuat terjadinya perubahan pandangan seseorang tentang suatu penyakit dan bertambahnya pengetahuan tersebut juga dapat membantu memperbaiki perilaku individu dari yang kurang baik menjadi baik, dan hal ini pun dapat membentuk rasa kepercayaan (Yanti, dkk, 2020).

Usia dapat mempengaruhi cara tangkap dan cara berpikir seseorang, karena dengan cukupnya umur maka tingkat kedewasaan dan kekuatan akan lebih baik dan proses berpikir dan melakukan pekerjaan dan dapat diperkirakan bahwa $I Q$ akan menurun bila sejalan dengan bertambahnya usia khususnya pada beberapa kemampuan yang lain misalnya kosa kata dan pengetahuan umum. Selain itu pendidikan juga diperlukan agar mendapatkan informasi lainnya seperti hal-hal yang mendukung tentang kesehatan, sehingga hal tersebut dapat meningkatkan kualitas hidup seseorang. Pendidikan merupakan faktor utama yang berperan penting dalam memperbanyak informasi dan pengetahuan seseorang dan pada umumnya semakin tinggi pendidikan seseorang maka akan makin mudah untuk menerima informasi dan sebaliknya bila seseorang 
memiliki tingkat pendidikan yang rendah hal tersebut dapat menghambat perkembangan sikap orang tersebut dalam menerima informasi yang diberikan (Moudy \& Syakurah, 2020).

Permasalahan masyarakat pada masa pandemi covid-19 ini adalah upaya preventif untuk menghentikan penyebaran covid-19. Masyarakat belum sepenuhnya menyadari bahwa kebijakan pemerintah tentang penerapan protokol kesehatan adalah langkah yang dapat menghentikan penyebaran covid-19. Sehingga inilah yang menjadi alasan penelitian ini dilakukan faktor-faktor apa saja yang mempengaruhi perilaku pencegahan covid-19 di tengah masyarakat.

\section{METODE PENELITIAN}

Jenis penelitian ini adalah penelitian kuantitatif dengan pendekatan observasional analitik yakni penelitian yang hanya mengamati saja tanpa memberikan intervensi dan dianalisis dengan menggunakan uji hipotesis. Rancangan penelitian yang digunakan adalah crossectional study yaitu rancangan penelitian yang pengukuran variabel bebas dan variabel terikat dilakukan pada waktu yang bersamaan.

Penelitian dilaksanakan di RW 05 Kelurahan Kapasa Makassar pada 9-15 Maret 2021. Populasinya adalah seluruh warga RW 05 Kelurahan Kapasa Makassar yang berjumlah 1.228 jiwa. Teknik sampling yang digunakan adalah nonprobability sampling dengan pendekatan teknik consecutive sampling yaitu cara pengambilan sampel dengan memilih setiap individu yang berada dalam populasi dan memenuhi kriteria inklusi yaitu warga yang berdomisili di RW 05 Kelurahan kapasa, berusia 11-80 tahun, bersedia menjadi responden dan dapat membaca dan menulis. Setelah memenuhi kriteria lalu diambil sampel sampai berjumlah 100 orang warga masyarakat.

Instrumen yang digunakan untuk mengukur variabel yang diteliti berupa kuesioner, merupakan sejumlah pertanyaan tertulis yang digunakan untuk memperoleh informasi dari responden. Karena kuesioner dibuat sendiri oleh peneliti sehingga sebelum digunakan terlebih dulu dilakukan uji validitas dan reliabilitas. Untuk uji validitas dan reliabilitas menggunakan uji statistik Pearson Product Moment berturut-turut melihat nilai korelasi jika $r_{\text {hitung }}>r_{\text {tabel }}$ maka item tersebut valid sedangkan untuk mengetahui kuesioner reliabel dengan membandingkan nilai alpha cronbach hitung dengan nilai alpha cronbach kritis. Data yang diperoleh diolah dengan tahap editing, coding, tabulating. Data dianalisis secara univariat dan bivariat menggunakan SPSS for Windows versi 24. Analisis univariat merupakan analisis yang dilakukan terhadap masing-masing variabel baik variabel bebas maupun variabel terikat untuk mendapatkan distribusi frekuensi dan persentase yaitu usia, jenis kelamin, tingkat pendidikan, pengetahuan dan perilaku pencegahan covid-19 sedangkan analisis bivariat bertujuan untuk melihat hubungan antara variabel bebas dengan variabel terikat yaitu hubungan usia, jenis kelamin, tingkat pendidikan, pengetahuan dengan perilaku pencegahan covid-19. Jenis hipotesis yang digunakan adalah hipotesis asosiasi atau korelatif.

\section{HASIL}

Tabel 1. menunjukkan bahwa sebagian besar responden berjenis kelamin perempuan yakni $61 \%$, jika berdasarkan usia kebanyakan berada pada usia dewasa yakni $75 \%$ responden, namun jika dilihat, tingkat pendidikan kebanyakan masih berada di sekolah menengah yaitu $47 \%$ responden, Pengetahuan dominan berada pada kategori baik mencapai 59\% dan perilaku pencegahan covid-19 dominan berada pada kategori baik sebanyak $78 \%$. 
Tabel 1. Distribusi Frekuensi Responden Berdasarkan Jenis Kelamin, usia, Tingkat Pendidikan, Pengetahuan dan Perilaku Pencegahan Covid-19

\begin{tabular}{|c|c|c|}
\hline Variabel & Frekuensi (f) & Persentase $\%$ \\
\hline \multicolumn{3}{|l|}{ Jenis Kelamin: } \\
\hline Laki-laki & 39 & 39,0 \\
\hline Perempuan & 61 & 61,0 \\
\hline \multicolumn{3}{|l|}{ Usia: } \\
\hline Dewasa & 75 & 75,0 \\
\hline Remaja & 25 & 25,0 \\
\hline \multicolumn{3}{|l|}{ Tingkat Pendidikan: } \\
\hline Tinggi & 35 & 35,0 \\
\hline Menengah & 47 & 35,0 \\
\hline Dasar & 18 & 35,0 \\
\hline \multicolumn{3}{|l|}{ Pengetahuan: } \\
\hline Baik & 59 & 59,0 \\
\hline Kurang & 41 & 41,0 \\
\hline \multicolumn{3}{|l|}{ Perilaku Pencegahan: } \\
\hline Baik & 78 & 78,0 \\
\hline Kurang & 22 & 22,0 \\
\hline Total & 100 & 100,0 \\
\hline
\end{tabular}

Tabel 2. mendeskripsikan bahwa berdasarkan hasil uji statistik Chi Square Tabel 2 x 2 yang dibaca pada Continuity Correction diperoleh nilai $\mathrm{p}=0,968$ dengan nilai $\alpha=0,05$ sehingga nilai $\mathrm{p}>\alpha$ artinya tidak ada hubungan yang signifikan antara jenis kelamin dengan perilaku pencegahan Covid-19. Hasil ini didukung oleh sel yang menjelaskan bahwa responden berjenis kelamin perempuan tetapi perilaku pencegahan Covid19 kurang sebanyak $14 \%$ responden dan responden yang berjenis kelamin laki-laki tetapi perilaku pencegahan Covid-19 baik sebanyak $31 \%$.

Tabel 2. Analisis Hubungan Jenis Kelamin Dengan Perilaku Pencegahan Covid-19

\begin{tabular}{cccccccc}
\hline & \multicolumn{5}{c}{ Perilaku Pencegahan Covid-19 } & \multirow{2}{*}{ Nilai $\rho$} \\
\cline { 2 - 6 } Jenis & \multicolumn{2}{c}{ Baik } & \multicolumn{2}{c}{ Kurang } & \multicolumn{2}{c}{ Total } & \\
\cline { 2 - 6 } & $\mathrm{f}$ & $\%$ & $\mathrm{f}$ & $\%$ & $\mathrm{f}$ & $\%$ & \\
Kelamin & 47 & 47 & 14 & 14 & 61 & 61,0 & \multirow{2}{*}{0,968} \\
Perempuan & 31 & 31 & 8 & 8 & 39 & 39,0 & \\
\hline Laki-laki & 78 & 78 & 22 & 22 & 100 & 100,0 & \\
\hline
\end{tabular}

Tabel 3. Mendeskripsikan hubungan usia dengan perilaku pencegahan Covid-19. Hasil uji statistik Chi Square Tabel 2 × 2 yang dibaca pada Continuity Correction diperoleh nilai $\mathrm{p}=0,026$ dengan nilai $\alpha=0,05$ sehingga nilai $\mathrm{p}<\alpha$ artinya terdapat hubungan yang signifikan antara usia dengan perilaku pencegahan Covid19. Hasil ini didukung oleh sel yang menjelaskan bahwa responden dengan kategori usia dewasa memiliki perilaku pencegahan Covid-19 baik sebanyak 63\% dan responden dengan kategori usia remaja kurang dalam perilaku pencegahan Covid-19 sebanyak $10 \%$. 
Tabel 3. Analisis Hubungan Usia Dengan Perilaku Pencegahan Covid-19

\begin{tabular}{|c|c|c|c|c|c|c|c|}
\hline \multirow{3}{*}{ Usia } & \multicolumn{6}{|c|}{ Perilaku Pencegahan Covid-19 } & \multirow[t]{3}{*}{ Nilai $\rho$} \\
\hline & \multicolumn{2}{|c|}{ Baik } & \multicolumn{2}{|c|}{ Kurang } & \multicolumn{2}{|c|}{ Total } & \\
\hline & $f$ & $\%$ & $f$ & $\%$ & $f$ & $\%$ & \\
\hline Dewasa & 63 & 63 & 12 & 12 & 75 & 75,0 & \multirow{2}{*}{0,026} \\
\hline Remaja & 15 & 15 & 10 & 10 & 25 & 25,0 & \\
\hline Total & 78 & 78 & 22 & 22 & 100 & 100,0 & \\
\hline
\end{tabular}

Tabel 4. mendeskripsikan bahwa berdasarkan hasil uji statistik Chi Square Tabel 3 x 2 yang dibaca pada Pearson Chi Square diperoleh nilai $\mathrm{p}=0,001$ dengan nilai $\alpha=0,05$ sehingga nilai $\mathrm{p}<\alpha$ artinya terdapat hubungan yang signifikan antara tingkat pendidikan dengan perilaku pencegahan Covid-19. Hasil ini didukung oleh sel yang menjelaskan bahwa responden dengan tingkat pendidikan tinggi memiliki perilaku pencegahan Covid-19 yang baik sebanyak 30\% serta responden dengan tingkat pendidikan dasar memiliki perilaku pencegahan Covid-19 yang kurang sebanyak $10 \%$ responden.

Tabel 4. Analisis Hubungan Tingkat Pendidikan Dengan Perilaku Pencegahan Covid-19

\begin{tabular}{|c|c|c|c|c|c|c|c|}
\hline \multirow{3}{*}{$\begin{array}{l}\text { Tingkat } \\
\text { Pendidikan }\end{array}$} & \multicolumn{6}{|c|}{ Perilaku Pencegahan Covid-19 } & \multirow[t]{3}{*}{ Nilai $\rho$} \\
\hline & \multicolumn{2}{|c|}{ Baik } & \multicolumn{2}{|c|}{ Kurang } & \multicolumn{2}{|c|}{ Total } & \\
\hline & $\mathrm{f}$ & $\%$ & $f$ & $\%$ & $\mathrm{f}$ & $\%$ & \\
\hline Tinggi & 30 & 30,0 & 5 & 5,0 & 35 & 35,0 & \\
\hline Menengah & 40 & 40,0 & 7 & 7,0 & 47 & 47,0 & 0,001 \\
\hline Dasar & 8 & 8,0 & 10 & 10,0 & 18 & 18,0 & \\
\hline Total & 78 & 78,0 & 22 & 22,0 & 100 & 100,0 & \\
\hline
\end{tabular}

Tabel 5. mendeskripsikan bahwa berdasarkan hasil uji statistik Chi Square Tabel 2 x 2 yang dibaca pada Continuity Correction diperoleh nilai $\mathrm{p}=0,000$ dengan nilai $\alpha=0,05$ sehingga nilai $\mathrm{p}<\alpha$ artinya terdapat hubungan yang signifikan antara pengetahuan dengan perilaku pencegahan Covid-19. Hasil ini didukung oleh sel yang menjelaskan bahwa responden dengan pengetahuan baik perilaku pencegahan Covid-19 baik sebanyak $57 \%$ serta responden dengan pengetahuan kurang perilaku pencegahan Covid-19 kurang sebanyak $20 \%$ responden.

Tabel 5. Analisis Hubungan Pengetahuan Dengan Perilaku Pencegahan Covid-19

\begin{tabular}{|c|c|c|c|c|c|c|c|}
\hline \multirow{3}{*}{ Pengetahuan } & \multicolumn{6}{|c|}{ Perilaku Pencegahan Covid-19 } & \multirow[t]{3}{*}{ Nilai $\rho$} \\
\hline & \multicolumn{2}{|c|}{ Baik } & \multicolumn{2}{|c|}{ Kurang } & \multicolumn{2}{|c|}{ Total } & \\
\hline & $\mathrm{f}$ & $\%$ & $\mathrm{f}$ & $\%$ & $\mathrm{f}$ & $\%$ & \\
\hline Baik & 57 & 57,0 & 2 & 2,0 & 59 & 59,0 & \multirow{3}{*}{0,001} \\
\hline Kurang & 21 & 21,0 & 20 & 20,0 & 41 & 41,0 & \\
\hline Total & 78 & 78,0 & 22 & 22,0 & 100 & 100,0 & \\
\hline
\end{tabular}

\section{DISKUSI}

Berdasarkan hasil uji hipotesis diperoleh bahwa tidak terdapat hubungan yang signifikan antara jenis kelamin dengan perilaku pencegahan Covid-19. Hasil ini didukung oleh nilai sel yang menjelaskan bahwa responden dengan jenis kelamin perempuan perilaku pencegahan Covid-19 kurang sebanyak 14\% responden serta berjenis kelamin laki-laki perilaku pencegahan Covid-19 baik sebanyak 31\% responden. Penelitian Istanti et al (2021) menjelaskan bahwa tidak ada hubungan antara jenis kelamin dengan penerapan protokol 
kesehatan tetapi kecenderungan menunjukkan bahwa responden yang berjenis kelamin perempuan akan lebih memiliki perilaku yang positif dalam mengimplementasikan protokol kesehatan covid-19. Sejalan dengan penelitian Wulandari et al (2020) yang mengatakan responden dengan jenis kelamin perempuan cenderung lebih memiliki pengetahuan yang sangat baik tentang perilaku pencegahan Covid-19 bila dibandingkan dengan jenis kelamin laki-laki. Penelitian lain menyatakan bahwa tidak ada hubungan antara jenis kelamin dengan perilaku penggunaan APD pada tenaga kesehatan di RSUD Banjarbaru ( $p$-value $=0,94)$, didukung oleh sel yang mendeskripsikan bahwa jenis kelamin perempuan tetapi perilaku penggunaan Alat Pelindung Diri kurang sebanyak 22(23,9\%) responden (Apriluana, Khairiyati, \& Setyaningrum, 2016). Pada penelitian Zhon (2020) ditemukan adanya suatu hubungan antara jenis kelamin dengan tindakan pencegahan terhadap covid-19, laki-laki lebih berisiko mempunyai perilaku yang kurang baik seperti bepergian tidak menggunakan masker saat ke tempat yang ramai dibandingkan dengan perempuan. Selain jenis kelamin pada penelitian ini ditemukan juga hubungan signifikan lainnya berupa kelompok usia, tingkat pendidikan, dan juga asal daerah yang berpengaruh pada pola pikir dan pemahaman masyarakat mengenai covid-19 (Moudy \& Syakurah, 2020). Menurut Notoatmodjo (2007), perbedaan nilai dan sifat antara yang berjenis kelamin laki-laki dan perempuan, dalam hal membuat keputusan dan praktek hidup. Laki-laki lebih cenderung menganggap pencapaian prestasi sebagai suatu persaingan serta mementingkan kesuksesan akhir (relative performance), sedangkan wanita lebih mementingkan self performance. Wanita akan lebih menitikberatkan pada pelaksanaan tugas dengan baik dan hubungan kerja yang harmonis, sehingga wanita akan lebih patuh terhadap peraturan yang ada.

Hasil uji statistik penelitian ini, juga menjelaskan terdapat hubungan yang signifikan antara usia dengan perilaku pencegahan covid-19 masyarakat, yang didukung oleh nilai sel yang menjelaskan bahwa usia dewasa perilaku pencegahan baik sebanyak $63 \%$ responden dan usia remaja perilaku pencegahan kurang sebanyak 25\% responden. Pada penelitian Afrianti (2021) dijelaskan bahwa usia yang dewasa akan memiliki perilaku yang baik dibandingkan dengan yang berusia remaja, ditambahkannya bahwa perilaku individu yang baik akan semakin meningkat seiring dengan bertambahnya usia individu tersebut. Budiman (2013) juga mengatakan umur individu dapat mempengaruhi daya tangkap dan cara berpikirnya. Karena dengan meningkatnya umur seseorang akan lebih meningkat juga daya tangkap dan cara pikirnya sehingga pengetahuan yang didapatkan akan meningkat juga. Hasil penelitian Istanti et al (2021) menjelaskan bahwa salah satu faktor yang memiliki hubungan dengan perilaku pencegahan covid-19 adalah usia. Bertambahnya umur membuat seserorang semakin dewasa serta memiliki rasa tanggungjawab dan kepedulian yang meningkat. Masyarakat yang memiliki umur lebih dewasa rasa tanggungjawab dan kepedulian terhadap diri sendiri serta lingkungannya meningkat. Hal ini selaras dengan yang disampaikan Karuniawati \& Berlina Putrianti (2020) bahwa umur merupakan salah satu faktor yang bisa menjelaskan kematangan fisik, psikis dan sosial dari individu serta setidaknya berpengaruh dalam proses pembelajaran.

Hasil uji statistik juga menjelaskan bahwa ada hubungan antara tingkat pendidikan dengan perilaku pencegahan Covid-19 masyarakat RW 05 Kelurahan Kapasa Makassar, yang didukung oleh nilai sel pada tabel tabulasi silang yang menyatakan responden dengan tingkat pendidikan tinggi memiliki perilaku pencegahan Covid yang baik sebanyak 30\% responden, tingkat pendidikan menengah yang memiliki perilaku pencegahan covid-19 baik sebanyak $40 \%$ responden dan tingkat pendidikan dasar yang memiliki perilaku pencegahan Covid-19 kurang sebanyak $10 \%$ responden. Hasil ini sejalan dengan penelitian yang dilakukan oleh Studi et al (2020), yakni sebagian besar dari responden yang memiliki pendidikan menengah dan tinggi selalu atau sering mencuci tangan, menggunakan hand sanitizer, memakai masker saat bepergian, melakukan isolasi mandiri saat sakit dan menjaga jarak dari orang atau keluarga yang baru saja melakukan kegiatan dari luar daerah serta mengkonsumsi makan bergizi untuk menjaga sistem kekebalan tubuh. Juga didukung penelitian Zhong et al (2020) dimana saat dilakukan penelitian pertama pada masyarakat Cina pada awal mula muncul virus corona didapatkan bahwa masyarakat memiliki pendidikan dan pengetahuan yang baik. Jadi semakin tinggi tingkat pendidikan seseorang, maka dapat dikatakan hal tersebut membuat seseorang menjadi lebih mudah memahami tentang sesuatu sehingga pengetahuannya pun lebih tinggi dan hal itu dapat mempengaruhi perilaku pencegahan orang tersebut.

Hasil uji statistik juga menjelaskan bahwa ada hubungan yang signifikan antara pengetahuan dengan perilaku pencegahan Covid-19 masyarakat RW 05 Kelurahan Kapasa Makassar. Hasil uji statistik didukung oleh sel yang menjelaskan bahwa responden yang memiliki pengetahuan yang baik akan memiliki perilaku pencegahan Covid-19 yang baik pula sebanyak 57\% dan responden yang memiliki pengetahuan yang kurang akan memiliki perilaku pencegahan Covid-19 yang kurang sebanyak 20\%. Hal ini selaras dengan penelitian Suryaningrum et al (2021) yang mengatakan bahwa sebagian besar masyarakat telah memahami bahwa Covid-19 merupakan suatu penyakit yang bisa ditularkan dan disebabkan oleh virus, serta dapat menyerang semua golongan masyarakat dengan tanda dan gejala seperti sesak napas atau sulitnya bernapas, demam atau panas tinggi dan batuk. Dan dijelaskan pula masyarakat sudah tahu bahwa penyakit Covid-19 bisa tertular dengan melalui kontak fisik atau langsung dengan orang yang telah positif maupun tertular melalui droplet 
yang tersebar melalui udara sekitar. Hasil penelitian ini pun menunjukkan tingkat pengetahuan responden tentang Covid-19 yang baik lebih besar dari tingkat pengetahuan yang cukup sehingga disimpulkan bahwa sebagian besar responden memiliki pengetahuan yang baik tentang Covid-19. Hasil penelitian Zhong et al (2020) menyatakan bahwa pengetahuan yang tinggi akan menjadi penting dalam upaya menerapkan pencegahan covid-19 seperti tidak melakukan perjalanan ke lingkungan yang ramai dan memakai masker dengan baik.

Pengetahuan memiliki peran yang penting untuk bisa menentukan tindakan atau perilaku seseorang secara nyata karena hal ini bisa membentuk sebuah rasa percaya yang pada akhirnya memberi dasar dalam mengambil sebuah keputusan saat menentukan perilaku yang akan dilakukan pada satu objek tertentu. Seperti yang dikatakan Prihantana \& Wahyuningsih (2016) yaitu pengetahuan seseorang mempunyai hubungan yang kuat dengan ketepatan dan kecepatan dalam mengambil keputusan sebab pengetahuan adalah landasan seseorang dalam menentukan sebuah pilihan yang menurutnya baik dan tepat. Notoatmodjo (2007), mengatakan pengetahuan merupakan kekayaan mental secara langsung atau tidak langsung turut memperkaya kehidupan kita. Setiap pengetahuan mempunyai ciri-ciri yang spesifik mengenai apa, bagaimana dan untuk apa. Pengetahuan merupakan fungsi dari sikap, menurut fungsi ini manusia mempunyai dorongan dasar untuk tahu, untuk mencapai penalaran dan untuk mengorganisasikan penalaran.

\section{KESIMPULAN}

Sebagai kesimpulan di dalam penelitian ini adalah pengetahuan dan perilaku pencegahan Covid-19 masyarakat dominan berada pada kategori baik. Ada hubungan yang signifikan antara usia dengan perilaku pencegahan Covid-19 artinya bahwa semakin dewasa usia seseorang maka perilaku pencegahan Covid-19 semakin baik. Ada hubungan yang signifikan antara tingkat pendidikan dengan perilaku pencegahan Covid19 pada masyarakat bermakna bahwa semakin tinggi tingkat pendidikan masyarakat semakin baik perilaku pencegahan Covid-19. Hal yang sama juga semakin baik pengetahuan masyarakat maka semakin baik pula perilaku pencegahan Covid-19 dan tidak ada hubungan antara jenis kelamin dengan perilaku pencegahan Covid-19 artinya apapun jenis kelamin seseorang dapat membuat seseorang berperilaku pencegahan Covid19 baik ataupun kurang. Orang yang sudah berusia kategori dewasa, tingkat pendidikannya tinggi dan pengetahuan baik maka perilaku pencegahan covid-19 juga baik. Sehingga perlu kedewasaan, peningkatan kualifikasi pendidikan dan pengetahuan yang baik agar perilaku pencegahan covid-19 juga baik. Edukasi tentang penerapan protokol kesehatan terus digalakan terhadap semua lapisan masyarakat sebab pengetahuan yang baik dapat merubah perilaku pencegahan yang masih kurang agar menjadi lebih baik.

\section{DAFTAR PUSTAKA}

Afrianti, N. (2021). Faktor-Faktor yang mempengaruhi kepatuhan masyarakat terhadap protokol kesehatan covid-19. Jurnal Ilmiah STIKES Kendal, 11(1), 113-124.

Budiman, A. (2013). Kapita Selekta Kuesioner: Pengetahuan dan Sikap dalam Pencegahan Kesehatan. Salemba Medika.

Dai, N. F. (2020). Stigma masyarakat terhadap pandemi covid-19. Stigma masyarakat terhadap pandemi covid-19, 66-73.

Dewi, E. U. (2020). Faktor-faktor yang mempengaruhi perilaku masyarakat dalam pencegahan penularan covid-19. Journal of Chemical Information and Modeling, 53(9), 1689-1699.

Dr.dr. Hans Tandra. (2020). Virus Corona Baru COVID-19.

F. Nur arafa. (2020). Pengaruh covid 19 terhadap mortalitas dan ketenagakerjaan di indonesia. Jurnal UNPAS, 7(2), 1-16.

Grace, C. (2020). Manifestasi Klinis dan Perjalanan Penyakit pada Pasien Covid-19. Majority, 9, 49-55.

Hasil, A., Matematika, B., Didik, P., Bahasan, P., Berdasarkan, L., Taksonomi, K., Kelas, B., Barru, K., Tarbiyah, F., Keguruan, D. A. N., \& Makassar, U. I. N. A. (2017). Analisis hasil belajar matematika peserta didik pada pokok bahasa lingkaran berdasarkan ranah kognitif taksonomi bloom kelas viii mts al-ikhlas addary ddi takkalasikabupaten barru.

Ikawaty, R. (2020). Dinamika interaksi reseptor ACE2 dan SARS-cov-2 terhadap manifestasi klinis COVID19. KELUWIH: Jurnal Kesehatan Dan Kedokteran, 1(2), 18. diakses dari https://journal.ubaya.ac.id/index.php/kesdok/article/view/2869

Istanti, N., Erlita, Y. D., Ringroad, J., Blado, S., Lor, B., Depok, C., \& Yogyakarta, S. (2021). Perilaku protokol kesehatan covid-19 pada pedagang pasar tradisional. 13, 267-274.

Journal, M. N., \& Issn, P.-. (2020). Analisis pengetahuan dan perilaku masyarakat di kelurahan baru kotawringin barat tentang covid-19. 2(September), 780-790.

Karuniawati, B., \& Berlina Putrianti. (2020). Gambaran perilaku hidup bersih dan sehat (PHBS) dalam pencegahan penularan covid-19. Jurnal Kesehatan Karya Husada, 8(2), 34-53. dari 
http://jurnal.poltekkeskhjogja.ac.id/index.php/jkkh/article/view/411

Luparello, R. C. (2014). Hubungan pengetahuan dengan perilaku perempuan obesitas tentang pencegahan risiko penyakit akibat obesitas di desa slahung wilyah kerja puskesmas slahung. Pontificia Universidad Catolica Del Peru, 8(33), 44.

Moudy, J., \& Syakurah, R. A. (2020b). Pengetahuan terkait usaha pencegahan Coronavirus Disease (COVID-19) di indonesia. Higeia Journal of Public Health Research and Development, 4(3), 333-346. https://doi.org/10.15294/higeia.v4i3.37844

Mujiburrahman, Riyadi, M. E., \& Ningsih, M. U. (2020). Pengetahuan berhubungan dengan peningkatan perilaku pencegahan COVID-19 di masyarakat. Jurnal Keperawatan Terpadu, 2(2), 130-140. dari http://www.elsevier.com/locate/scp

Munthe, S. A., Manurung, J., Rosa, L., \& Sinaga, V. (2020). Penyuluhan dan sosialisasi masker di desa sifahandro kecamatan sawo sebagai bentuk kepedulian terhadap masyarakat ditengah mewabahnya virus covid-19. Jurnal Abdimas Mutiara, 1(September), 115-123.

Nakoe, R., S Lalu, N. A., \& Mohamad, Y. A. (2020). Perbedaan efektivitas hand-sanitizer dengan cuci tangan menggunakan sabun sebagai bentuk pencegahan covid-19. Jambura Journal of Health Sciences and Research, 2(2), 65-70. dari https://doi.org/10.35971/jjhsr.v2i2.6563

Nidaa, I. (2021). Gambaran pengetahuan masyarakat pekalongan tentang covid-19. Jurnal Litbang Kota Pekalongan, 19 , 64-73.

dari https://jurnal.pekalongankota.go.id/index.php/litbang/article/viewFile/128/125

Nofia, V. R. (2016). Hubungan pengetahuan dan jenis kelamin perawat dengan penerapan komunikasi terapeutik kepada pasien vino. Jurnal Medika Saintika, 7(2), 55-63.

Nurislaminingsih, R. (2020). Layanan pengetahuan tentang COVID-19 di lembaga informasi. Tik Ilmeu: Jurnal Ilmu Perpustakaan Dan Informasi, 4(1), 19. diakses dari https://doi.org/10.29240/tik.v4i1.1468

Pratiwi, M. S. A., Yani, M. V. W., Putra, A. I. Y. D., Mardiana, I. W. G., Adnyana, I. K. A., Putri, N. M. M. G., Karang, N. P. S. W. A., \& Setiawan, I. P. Y. (2020). Hubungan karakteristik individu terhadap perilaku mengenai covid-19 di desa gulingan, mengwi, bali. Jurnal Kesehatan, 13(2), 112. diakses dari https://doi.org/10.24252/kesehatan.v1i1.16340

Prayitno, S. A., Pribadi, H. P., Ifadah, R. A., Studi, P., Pangan, T., Pertanian, F., Fisioterapi, P. S., \& Kesehatan, F. (2020). Peran serta dalam melaksanakan protokol pencegahan penyebaran corona virus disease (covid-19) pada masyarakat. DedikasiMU (Journal of Community Service), 2(3), 504-510.

Prihantana, A. S., \& Wahyuningsih, S. S. (2016). Hubungan pengetahuan dengan tingkat kepatuhan pengobatan pada pasien tuberkulosis di RSUD dr. Soehadi prijonegoro sragen. Farmasi Sains Dan Praktis, II(1), 47.

Purnamasari, I., \& Raharyani, A. E. (2020). Tingkat pengetahuan dan perilaku masyarakat kabupaten wonosobo tentang covid-19. Jurnal Ilmiah Kesehatan, Mei, 33-42. diakses dari https://ojs.unsiq.ac.id/index.php/jik/article/view/1311/783

Sari, A. R., \& Dkk. (2020). Perilaku pencegahan covid-19 ditinjau dari karakteristik individu dan sikap masyarakat. Journal of Chemical Information and Modeling, 53(9), 1689-1699.

Sarkawi, D. (2015). Pendidikan lingkungan dan pembangunan berkelanjutan, xvi(september), 101-114. diakses dari https://doi.org/10.21009/PLPB

Sataloff, R. T., Johns, M. M., \& Kost, K. M. (2020). Tata Kelola Covid-19 di Indoneisa.

Studi, P., Keperawatan, I., Kedokteran, F., Sam, U., Studi, P., \& Keperawatan, I. (2020). Tingkat pengetahuan dan perilaku pencegahan coronavirus disease 2019 (COVID-19) pada masyarakat sulawesi utara lenny gannika. 16(2), 83-89.

Suryaningrum, F. N., Rahardjo, M., Kesehatan, P., Fakultas, L., Masyarakat, K., Diponegoro, U., Lingkungan, B. K., Kesehatan, F., \& Universitas, M. (2021). Hubungan pengetahuan dan persepsi masyarakat dengan upaya pencegahan covid-19 di kelurahan srondol wetan, semarang. 9, 257-263.

Susilo, A., Rumende, C. M., Pitoyo, C. W., Santoso, W. D., Yulianti, M., Herikurniawan, H., Sinto, R., Singh, G., Nainggolan, L., Nelwan, E. J., Chen, L. K., Widhani, A., Wijaya, E., Wicaksana, B., Maksum, M., Annisa, F., Jasirwan, C. O. M., \& Yunihastuti, E. (2020). Coronavirus disease 2019: tinjauan literatur terkini. Jurnal Penyakit Dalam Indonesia, 7(1), 45. https://doi.org/10.7454/jpdi.v7i1.415

Tess Panington. (2020). Panduan kesiapsiagaan hadapi virus corona.

Usman, S., Budi, S., \& Nur Adkhana Sari, D. (2020). Pengetahuan dan sikap mahasiswa kesehatan tentang pencegahan covid-19 di indonesia. / Jurnal Ilmu Keperawatan Dan Kebidanan, 11(2), 410-414.

Veronica, R. (2013). Hubungan tingkat pengetahuan perawat dengan tindakan perawatan bblr di ruang ICU Rumah Sakit Awal Bross Makassar.

Wulandari, A., Rahman, F., Pujianti, N., Sari, A. R., Laily, N., Anggraini, L., Muddin, F. I., Ridwan, A. M., Anhar, V. Y., Azmiyannoor, M., \& Prasetio, D. B. (2020). Hubungan karakteristik individu dengan 
pengetahuan tentang pencegahan coronavirus disease 2019 pada masyarakat di kalimantan selatan. Jurnal Kesehatan Masyarakat Indonesia, 15(1), 42. diakses dari https://doi.org/10.26714/jkmi.15.1.2020.42-46

Yanti, N. P. E. D., Nugraha, I. M. A. D. P., Wisnawa, G. A., Agustina, N. P. D., \& Diantari, N. P. A. (2020). Gambaran pengetahuan masyarakat tentang covid-19 dan perilaku masyarakat di masa pandemi covid-19. Jurnal Keperawatan Jiwa, Vol. 8 No.(3), 485-490.

Zhong, B. L., Luo, W., Li, H. M., Zhang, Q. Q., Liu, X. G., Li, W. T., \& Li, Y. (2020). Knowledge, attitudes, and practices towards COVID-19 among chinese residents during the rapid rise period of the COVID19 outbreak: A quick online cross-sectional survey. International Journal of Biological Sciences, 16(10), 1745-1752. https://doi.org/10.7150/ijbs.45221 